\title{
National identity as the basis for the formation of patriotism among the younger generation of Russians
}

\author{
Olga V. Semaeva * \\ Plekhanov Russian University of Economics: 117997, Moscow, Russian Federation
}

\begin{abstract}
The article deals with the issues of forming a patriotic attitude of young Russian citizens to their country. The paper analyzes the results of various sociological studies that indicate that measures to form patriotism among the younger generation are not sufficiently effective and considers the causes underlying this situation. The article analyzes important historical events that determined the vector of development of the Russian state in different historical epochs and the activity of Patriotic citizens of Russia, who chose national values over the ideology promoted by political elites. The article presents the results of a survey conducted among students of of Plekhanov Russian University of Economics, the purpose of which was to determine the attitude of modern University students to the problem of national identification and patriotism.
\end{abstract}

\section{Introduction}

Patriotic education of Russian citizens is a matter of national importance. There is a state program "Patriotic education of citizens of the Russian Federation for 2016-2020" [1]; secondary and higher educational institutions hold scientific and practical conferences, organize discussions and competitions on the topic of forming the civil identity of Russians, universities introduce such subjects as "the History of the great Patriotic war" into the curriculum.

According to the developers of the program "Patriotic education of Russian citizens for 2016-2020", approved by Dmitry Medvedev, it will become a "cementing Foundation" and will contribute to "even greater consolidation of Russian society".

\section{Materials and Methods}

According to recent sociological research, the efforts made by state departments in this direction are not always effective. The study conducted on the basis of the North-Eastern Federal University named after M. K. Amosov, revealed the fact that the majority of respondents $(72.3 \%)$ consider themselves patriots, but at the same time, almost half of them

\footnotetext{
* Corresponding author: ORCID: 0000-0001-7457-1314 semaewa.olga@yandex.ru
} 
(58.5\%) would like to live and be born in another country, 28 people (21.5\%) could not call any of their friends a patriot. "[2]

Pustoplesnova O. O points to the fact that due to the complex social-economic reforms of Russian society, a significant part of young people have lost such traditional moral and psychological traits as romanticism, selflessness, readiness for feats, honesty, conscientiousness, faith in goodness and justice, the desire for truth and the search for an ideal, for the positive realization of not only personal, but also socially significant interests and goals. [3] The results of her research among secondary school students in grades 8-11 allow her to conclude: "the influence of the macro-society has a negative impact on the formation of the moral foundations of the younger generation, despite all the state programs adopted and the great work carried out by the Lyceum." [3]

Chita ethnographer and sociologist, PhD, head of the Laboratory of Applied Sociology of the Institute of Baikal state University of Economics and law Alexey Yankov says in his report "The Youth of Transbaikalia and the Values of Patriotism: a Sociological Study": "the youth of Transbaikalia is quite patriotic, and the older generation, I think, has no reason to worry". At the same time, the results of his research show that only $5.8 \%$ of respondents gave a positive answer to the question about the effectiveness of the system of state Patriotic education of Russian citizens, but $47 \%$ of respondents consider it ineffective. [4]

According to sociological research, the causes underlying the ineffectiveness of Patriotic education lie in the difficult socio-economic situation in the country. [2];[3]

Researchers also associate this problem with "a significant failure in spiritual and moral education in the late twentieth and early twenty-first centuries." [5]

In addition, Western countries are doing everything possible to "redraw the idea of the world today and the world of the past in young minds.»[5]. In this way "they want to deprive us of our history, falsifying its glorious pages, they are trying to instill in us a false sense of guilt for the actions of our ancestors." [6]. Unfortunately, the results of rewriting history textbooks," repentance", and shifting the emphasis are now evident in the difficult political and economic situation in the neighboring Slavic States.

However, the problem of devaluing the concept of patriotism is not unique to Russia. Scientists associate it with the crisis of the Westphalian system of the world order $[5,7]$ and the processes of globalization that are characteristic of the information age. The processes of globalization lead to the blurring of borders between states, as modern events show this does not contribute to their stability and to the prosperity of their citizens. Russia is no exception, and therefore the problem of educating a sense of national identity is particularly relevant.

It is impossible to disagree with the opinion of Professor V. V. Kochetkov that "...in troubled times of change and upheaval, when the past is unbearable and the future is uncertain, the question of identity comes to the fore. It sets the direction of development, allows you to clearly define national interests, and distinguish friends from enemies. The proverb says "a Ship that doesn't know where to go will never have a fair wind." [8]

In the book "Notes of a stubborn man. Byl " Russian actor and publicist I. Okhlobystin raises an important problem of forming the national identity of the Russian person: "I opened my passport and remembered that there is no "nationality" column in it. I also remembered that they canceled the column at the dawn of cooperation for some human rights reasons. Then they promised to return it, with optional participation, but never did. Then they took the polls, and according to them, the overwhelming majority of the people were for the return of the column. Alas. They did not return it. It hurts me.

This is the land of my people, which means it is mine. I'm not going to fence it in and commit lawlessness, but this is my land. It is important for me to have the right to this statement. It makes me involved in what is happening on this earth, encourages me to act for its $\operatorname{good} . . . "[9]$ 
The author rightly points out the high degree of importance of national identification: Russian literature, Russian music, Russian painting, and so on. Let me at least have something to do with this: sometimes I want to brag about the achievements of my fellow countrymen, and not of my fellow citizens, with all due respect to the latter.»

In our opinion, the issue of education of patriotism is inextricably linked with the phenomenon of national identification. Scientists define the concept of national identity in different ways, but they all agree that it is formed on the common cultural and historical experience of people living on the same geographical territory. "The group is formed by common roots, i.e. history... Cultural homogeneity is explained by the transfer from generation to generation of common values and forms of being" $[6,10]$

S. Huntington believes that" there is no nation without a national history that highlights in people's memories the glorious events of the past, wars and victories, failures and defeats, images of heroes and villains " [11].

V. V. Kochetkov also believes that such factors as common history and culture play a decisive role in the formation of national identity: "the genesis and existence of the modern form of statehood are closely related to the formation and development of such a type of social community as a nation. Let's note the main factors of the nation's development:

1) community of the territory of residence, which contributes to the formation of proximity in the perception of natural phenomena and the consolidation of social community;

2) community of economic activity, determined by the same resources, forming a similar type of economic activity;

3) cultural unity, reflected in the community of language, religion, social norms of behavior;

4) common ethnic origin of people, although this factor is not decisive;

5) common historical experience, a sense of common fate, common past, present and future;

6) common national identity. The formation of national identity was the main factor in the formation of the nation. "[8]

The question is who exactly defines the "heroes and villains of the nation", thus influencing the formation of society's attitude to certain events. On the example of our country, we see that historians interpret the same events differently in different historical periods of its existence. Then, following the logic, the next question arises as to how it is possible to force people to use ideology to abandon views on the main points of their existence, based both on their own life experience and on the historical experience of their ancestors.

V. A. Achkasov speaks about national identity in the context of the national narrative, he comes to the conclusion that "modern mass ideas about history are not the" natural memory of the nation" passed down from generation to generation, they are the result of professional agents of historical policy... As a result, each established nation has its own history (heroic or tragic with its own Pantheon of "heroes" and "villains"), which is not just a series of events, but a professionally organized " national narrative» [12]

What role do the participants of historical events themselves, the citizens of the country play in the organization of the "national narrative"? Analysis of the history of Russia, which was largely formed due to the exploits and heroism of the Russian people, clearly shows that it was the sense of national identity of Russians that prompted them to make decisions about their own actions in favor of the interests of the Motherland, and not their own.

Russia is a country with a unique history. The pursuit of universal justice has always been a distinctive characteristic of our nation. Unfortunately, all the democratic gains have come at a difficult price for our people. We can assume that it was the love of our country and the sense of patriotism of our people that saved the Russian state from collapse in various periods of its existence. 
For example, today historians have different opinions about the causes and significance of the events of October 1917. Many aspects of the Bolshevik revolution will remain controversial for a long time. The October revolution meant a radical change in the state system. The rule of the Soviets of People's Commissars replaced the rule of the monarchy. The new state proclaimed new values, new ideology, and new people came to the main political stage of the country.

New political elites began to create a new history of Russia. This was a period of severe trials for the country. The citizens had to take care on the one hand to preserve their own lives, and on the other, which is no less important, not to lose their self-identity, not to abandon the principles and rules of behavior that their parents had laid down in their minds since childhood.

It was not easy for those citizens of the country whose life principles ran counter to the ideology promoted by the new government. Suffice it to recall the position of the Cossacks. Nicholas II himself was the August ataman of all the Cossack troops.

The opinions of researchers of the problems of the formation of the Cossacks differ on many key issues, but no one disputes that they are a free, brave, and original people. The historian Karamzin said that these "brave knights ..." died "for freedom, Fatherland and faith»

There is no doubt that the patriotism of the Cossacks was based primarily on national identity rather than a new ideology. They had something to protect their land, home, national values, memory of ancestors, family, regardless of what political system was established in the country, and who formulated the ideological component of the state, which casts doubt on the claim by V.A. Achkasov that ideas about history are not "natural memory" transmitted from generation to generation"[12].

"Before the October revolution, the Cossacks served the Fatherland Faithfully. After the overthrow of the Tsar, they remained true to their ideals, for which they were arrested, repressed and deprived of their rights. Therefore, after the civil war, they were not called up for service for a long time" [13]

However, when in the late 1930s the threat of a major war became particularly real and the authorities realized the need to have in their service not just professionally trained, but really Patriotic soldiers, so the authorities partially returned to Cossacks their rights. They did not hold grudges and staffed 48 divisions by August 1941, and by December of the same year, 47 more cavalry divisions, largely with volunteers of non-conscripted age 45 and older. "[13]

Here it is necessary to point out that the Cossacks served the Russian land, regardless of the political structure of society established at one time or another. The fact is many of those awarded Soviet orders and medals wore them on their chests next to the St. George crosses received during their service in the tsarist army. This confirms the conclusion that the patriotism of the Cossacks was based on national identity, rather than a willingness to serve a political system based on a particular ideology.

"One of the outstanding Cossacks who selflessly defended his land was a resident of the Don stanitsa Konstantin Iosifovich Nedorubov. He was a full cavalier of St. George and received a sword with a gift inscription from the hands of S. M. Budyonny himself. This brave man was awarded the title Hero of the Soviet Union long before the end of the great Patriotic war. His gold Star flaunted on his chest next to the tsar crosses... "[13]

The life story of K. I. Nedorubov is a very illustrative example of how people who have a clear sense of national identity have been saving the country from collapse for more than a century, regardless of how modern historians try to describe the events taking place in the country.

If people Like K. I. Nedorubov put the interests of political power at the forefront, insisted on protecting the foundations of the monarchy or the Soviets in this particular case, it is not 
known whether Russia would exist as an administrative unit today. Fortunately, national interests, including the interests of family and friends, were more important for such people.

Objective facts clearly show that the main goal of Konstantin Iosifovich's life was to protect the Motherland, regardless of whether the state rewarded him for his services or not.

The attitude of K. I. Nedorubov to the Fatherland was not a unique phenomenon. Such facts are well known from the biographies of the writer V. P. Kataev, military commanders S. K. Timoshenko, I. V. Tyulenev, and others.

\section{Results and Discussion}

Taking into account all the facts mentioned above, it is necessary for the modern Russian ideologists to maintain constant feedback with the people they are creating a national historical narrative for. They ought to have a clear idea about what kind of heroes inspire the society, what values really matter to Russians and can unite them.

Speaking about the problem of national identity formation and a sense of patriotism among Russia's youth, I would like to cite the results of a survey conducted among the students of the $1^{\text {st }}, 2^{\text {nd }}$ and $3^{\text {rd }}$ years of Plekhanov Russian University of Economics. The purpose of the survey was to determine the attitude of modern students to the problem of protecting national values and, to understand what patriotism means to them. The survey participants were to choose one or more of the three answers to the suggested questions.

Table 1. Results of the survey among students of Plekhanov Russian University of Economics

\begin{tabular}{|c|c|c|}
\hline $\begin{array}{l}\text { 1. What do you know } \\
\text { about K. I. Nedorubov. }\end{array}$ & $\begin{array}{l}\text { 1. Hero Of The Soviet Union } \\
\text { 2. Full St. George's cavalier } \\
\text { 3. Don Cossack } \\
\text { 4. Nothing }\end{array}$ & $\begin{array}{l}48 \% \\
14 \% \\
15 \% \\
-\end{array}$ \\
\hline $\begin{array}{l}\text { 2. What do you know } \\
\text { about S. M. Budyonny }\end{array}$ & $\begin{array}{l}\text { 1. Hero of the Russian civil war of } 1917-1922 \\
\text { 2. Marshal of the Soviet Union } \\
\text { 3. Was awarded the George cross } \\
\text { 4. Nothing }\end{array}$ & $\begin{array}{l}16 \% \\
40 \% \\
15 \% \\
-\end{array}$ \\
\hline $\begin{array}{l}\text { 3. What do you know } \\
\text { about G. K Zhukov }\end{array}$ & $\begin{array}{l}\text { 1. Marshal of the Soviet Union } \\
\text { 2. Was awarded the St.George cross } \\
\text { 3.Hero of The Soviet Union } \\
\text { 4.Nothing }\end{array}$ & $\begin{array}{l}66 \% \\
8 \% \\
23 \% \\
- \\
\end{array}$ \\
\hline $\begin{array}{l}\text { 4. What do you know } \\
\text { about V.p. Kataev }\end{array}$ & $\begin{array}{l}\text { 1. Soviet writer } \\
\text { 2. Winner of The Stalin prize of the second degree } \\
\text { (1946) - for the story " Son of the regiment "(1945) } \\
\text { 3. For his service in the volunteer army of A. I. } \\
\text { Denikin was awarded two St. George crosses and the } \\
\text { Order of St. Anna, 4th class } \\
\text { 4. Nothing }\end{array}$ & $\begin{array}{l}45 \% \\
34 \% \\
14 \% \\
-\end{array}$ \\
\hline $\begin{array}{l}\text { 5. Which fact from the } \\
\text { biographies of K. I. } \\
\text { Nedorubov, G. K. } \\
\text { Zhukov, S. } \\
\text { Timoshenko, S. M. } \\
\text { Budyonny, I. V. Tyulenev, } \\
\begin{array}{l}\text { R. Ya. Malinovsky, I. V. } \\
\text { Meshcheryakov is most } \\
\text { respected }\end{array}\end{array}$ & $\begin{array}{l}\text { 1. Defended the Fatherland independent from the } \\
\text { existing political structure of the state. } \\
\text { 2. They wore the Tsar's awards next to the Soviet } \\
\text { ones. } \\
\text { 3. They were outstanding military commanders. } \\
\text { 4. None of the facts are worth respect }\end{array}$ & $\begin{array}{l}64 \% \\
5 \% \\
25 \% \\
-\end{array}$ \\
\hline $\begin{array}{l}\text { 6. What does patriotism } \\
\text { mean to you? (multiple } \\
\text { response options can be } \\
\text { selected at once) }\end{array}$ & $\begin{array}{l}\text { 1. Family, friends, hometown } \\
\text { 2. National history, culture, traditions } \\
\text { 3. Russia as an administrative unit } \\
\text { 4. I do not consider myself a patriot. }\end{array}$ & $\begin{array}{l}1.33 \% \\
1,2.37 \% \\
1,2,320 \% \\
4-\end{array}$ \\
\hline
\end{tabular}


It should be noted that none of the respondents chose the fourth option as the answer that indicates that students are aware of the basic facts of Russian history. At the same time, most of the respondents are mostly aware of the facts from the biographies of famous people mentioned in the questionnaire related to their achievements in the Soviet period of Russia. Only $14 \%$ know that K. I. Nedorubov was a full knight of St. George, 15\% know that S. M. Budyonny was awarded the St. George cross and mere $8 \%$ of the respondents are aware of the same fact from the biography of G. K. Zhukov, as well as only $14 \%$ of respondents are informed about V.P. Kataev's service in the white army.

At the same time, the overwhelming majority of students $-64 \%$ - expressed respect for all the mentioned heroes for defending their Fatherland and the state, regardless of its political structure and regardless of the repressions, the state authorities subjected them to.

The survey results also show that for the majority of young people $(70 \%)$ patriotism is primarily associated with the concept of the family. It is worth noting that for $37 \%$ of them, this concept also includes the cultural heritage of the country.

Analysis of the survey shows that modern students know the history and culture of their country and feel their involvement with everything that happened and is happening in their Homeland, but not at the global level of the whole country, but at the level of their closest society. They consider heroes those people who defended the values, associated with this society from their enemies: family, traditions, culture, often regardless of the repression they underwent. We can conclude they are the heroes whose biographies resonate with young people; their life story could become the basis of a certain ideology that unites young citizens of our state.

\section{Conclusion}

Summing up, it should be noted that research shows the ineffectiveness of the measures taken today to increase the Patriotic mood of Russian youth, caused by different factors $[2,3,4,5]$. The internal factors are difficult socio-economic situation in the country [2,3], failure in spiritual and moral education in the late XX early XXI centuries [5]. The external ones are sanctions by Western countries, the West's desire to "reshape" the historical events of the world level as well as to create a negative image of our country in the eyes of the world [5, 6], the crisis of the Westphalian system of world order [5], [7].

To create effective measures to foster patriotism, it is necessary to take into account the values and interests shared by young people themselves. The survey conducted among students of Plekhanov Russian University of Economics shows that facts of selfless feats of Russians performed in different historical epochs for the prosperity of the Fatherland regardless of whether they shared the political ideology of the state or not resonate with the students. Extensive coverage of life story of such people can contribute to the formation of national identity and patriotism of young Russian citizens.

Thus, practice shows that the younger generation of Russians has a request to study the facts that prove that a Russian has such qualities as courage, selflessness, respect for family values and national traditions. Biographies of people who helped our state survive in different historical periods associated with the change of its political structure are interesting to modern students.

\section{References}

1. Decree of the Government of the Russian Federation No. 1493 of December 30, 2015

2. S.S. Yakovleva, A.D. Maksimova, About the results of the sociological survey "what is patriotism?» (2019), https://scienceforum.ru/ 
3. O.O. Pustoplesnova, The program of sociological research on the topic "Determining the level of formation of personal qualities of a citizen-patriot", https://infourok.ru/

4. A. Tarasov, "The Youth of Transbaikalia and the values of patriotism: according to sociological research", https://a-p-tarasov.livejournal.com

5. S. N. Tomilina, S.V. Manetskaya, The s cientific journal of the Kuban state agrarian University, 110(06) (2015)

6. V.P. Zinov'ev, S.G. Sulak, Rusich Russian Patriotism Today, 2 (40) (2015)

7. Tolobek Abdyrakhmanov, Journal "Innovative Science"

8. V. V. Kochetkov, Bullet Mosk. UN-TY.18. Sociology and political science, 2 (2012)

9. Ivan Okhlobystin " Notes of a stubborn man. Byl». (2019), https://www.litmir.me/

10. G. Noiriel Etat, nation et immigration (2005)

11. Samuel P. Huntington, Who are we? Challenges of American national identity (2004)

12. V.A. Achkasov, Management consulting, 10 (2018)

13. Cultural studies. Of the Russian Federation, https://kulturologia.ru/ 